\title{
NOTES
}

\section{PROSPECTUS LIABILITY AND RULE 10b-5: A SEQUEL TO BARCHRIS}

The judicial task of integrating the various federal provisions regulating securities transactions has nowhere proved more troublesome than in the courts' attempts to harmonize the express civil liability provisions of the Securities Act of $1933^{1}$ with the private right of action available under rule $10 \mathrm{~b}-5$ of the Securities and Exchange Commission. ${ }^{2}$ The rule, which applies to both purchases and sales, was designed primarily to provide the government with the same criminal and injunctive sanctions against fraudulent purchases of undervalued securities that section 17 of the $1933 \mathrm{Act}^{3}$ had provided

1. Securities Act of 1933, §§11, 12,15 U.S.C. $\$ \$ 77 \mathrm{k}, 771$ (1964) [hereinafter cited as the 1933 Act]. Section 11 imposes civil liability on issuers of registered securities when the registration statement is misleading. Section $12(1)$ imposes liability on anyone who offers or sells a security in violation of section 5, 15 U.S.C. \& 77e (1964), which generally prohibits the offering or selling of unregistered securities, subject to the exceptions listed in section 3(a), 15 U.S.C. $\S 77 c(a)$ (1964). Section 12(2) imposes liability on anyone who offers or sells either a registcred or an unregistered security, other than a government or bank security, by means of a prospectus or oral communication containing a material misstatement. See 3 L. Loss, SECURITIES REGULATION 1684 (1961) [hereinafter cited as Loss]. For the text of section 12(2), see note 6 infra. In addition, section 15, 15 U.S.C. $\$ 770$ (1964), imposes liability on anyone who "controls" a person liable under sections 11 or 12 . See note 59 infra and accompanying text.

2. 17 C.F.R. $\$ 240.10 b-5$ (1970). The text of rule $10 b-5$ is as follows:

It shall be unlawful for any person, directly or indirectly, by the use of any means or instrumentality of interstate commerce; or of the mails or of any facility of any national securities exchange,

(a) To employ any device, scheme, or artifice to defraud,

(b) To make any untrue statement of a material fact or to omit to state a material fact necessary in order to make the statements made, in the light of the circumstances under which they were made, not misleading, or

(c) To engage in any act, practice, or course of business which operates or would operate as a fraud or deceit upon any person, in connection with the purchase or sale of any security.

The rule was promulgated under section 10(b) of the Securities Exchange Act of 1934, 15 U.S.C. \& $78 \mathrm{j}$ (b) (1964) [hereinafter cited as the $1934 \mathrm{Act}$, which states in pertinent part that:

It shall be unlawful for any person . . .

- .

(b) To use or employ, in connection with the purchase or sale of any security . . . any manipulative or deceptive device or contrivance in contravention of such rules and regulations as the [Securities and Exchange] Commission may prescribe . . . .

3. Securities Act of 1933, $\S 17,15$ U.S.C. $\$ 77 q$ (1964). 
in cases involving the fraudulent sale of overvalued securities. The courts, however, found that the rule also provided the defrauded seller with a private remedy ${ }^{5}$ corresponding with the remedy expressly provided a defrauded buyer by section 12(2) of the 1933 Act. ${ }^{6}$ This would seem, in turn, to place the defrauded buyer at a disadvantage since the implied civil remedy of the defrauded seller is unencumbered by the many procedural restrictions of section $12(2){ }^{7}$ Thus, rule $10 \mathrm{~b}-5$

4. The language of section 17 of the 1933 Act is practically identical with that of rule $10 \mathrm{~b}-5$, except that it applies to sellers only.

The announced purpose of rule $10 \mathrm{~b}-5$ was to prohibit "individuals or companies from buying securities if they engage in fraud in their purchase." SEC Securities Act Release No. 3230 (May 21, 1942), reprinted in A. Bromberg, Securities LAw: FrAUD-SEC RuLE 10b-5, Appendix B, at 295 [hereinafter cited as BROMBerg]. The rule allowed the Commission to reach corporate insiders who were fraudulently purchasing securities on the basis of inside information for personal or corporate gain. Professor Bromberg suggests that the promulgation of the rule in 1942 was prompted by an upswing in the economy, which stimulated fraudulent purchases. BROMBERG $\$ 2.2$, at 20 . Use of the rule-making power followed an unsuccessful attempt by the Commission to have section 17 of the $1933 \mathrm{Act}$ amended so as to cover purchases as well as sales. 3 Loss 1426-27.

5. Kardon v. National Gypsum Co., 69 F. Supp. 512 (E.D. Pa. 1946), was the landmark decision and has been widely followed. See, e.g., Hooper v. Mountain States Sec. Corp., 282 F.2d 195 (5th Cir. 1960); Speed v. Transamerica Corp., 235 F.2d 369 (3d Cir. 1956); Fratt v. Robinson, 203 F.2đ 627 (9th Cir. 1953); Annot., 37 A.L.R.2d 649 (1954). But see Ruder, Civil Liability Under Rule 10b-5: Judicial Revision of Legislative Intent?, 57 Nw. U.L. REv. 627,633 (1963).

The two bases found for implied civil liability under the rule are: $A$ statutory basis in section 29 of the 1934 Act, 15 U.S.C. $\$ 78 \mathrm{cc}$ (1964), which declares contracts entered into in violation of any provision of the Act or any rule thereunder to be void as to that person violating such provision and thus implies the right to bring suit to have a contract so declared, see, e.g., Fratt $v$. Robinson, supra; and the common-law tort doctrine that a person injured by violation of a statute enacted for persons in his position is entitled to recover damages. See, e.g., Kardon v. National Gypsum Co., supra; W. PROSSER, TORTS $§ 35$, at 195-205 (3d ed. 1964) thereinafter cited as PRosSER]. See generally BromberG $\$ \S 2.4(1)(a)-(b)$, at 28-32.

6. 1933 Act $\S 12(2), 15$ U.S.C. $\S 771(2)$ (1964). The section states, in pertinent part, that: Any person who-

....

(2) offers or sells a security [other than a government or bank securityl . . . by means of a prospectus or oral communication which includes an untrue statement of a material fact or omits to state a material fact necessary in order to make the statements ... not misleading (the purchaser not knowing of such untruth or omission), and who shall not sustain the burden of proof that he did not know, and in the exercise of reasonable care could not have known, of such untruth or omission,

shall be liable to the person purchasing such security from him, who may sue either at law or in equity....

7. Section 13 of the 1933 Act, 15 U.S.C. $\$ 77 \mathrm{~m}$ (1964), requires that actions under sections 11 and $12(2)$ be brought within one year after the inaccuracy in the registration statement or prospectus was or should have been discovered. Rule 10b-5 actions are governed by generally longer state statutes of limitations. BROMBERG $\S 2.5(1)$, at 41 . Section 11 (e) of the $1933 \mathrm{Act}, 15$ 
has been construed by a number of courts so as to provide a private remedy for defrauded buyers as well as sellers. Early decisions simply assumed that a buyer as well as a seller had an implied right of action and never considered how that assumption affected the vitality of the buyer's express remedy under section $12(2) .{ }^{8}$ Even in more recent cases, where the possible effect on section 12(2) was considered, the courts have, for the most part, followed these early decisions and allowed a buyer to bring a rule $10 \mathrm{~b}-5$ action. ${ }^{9}$ Presently at issue is whether rule $10 \mathrm{~b}-5$ and section $12(2)$ are to be distinguished on the basis of the theory of tort liability underlying each. ${ }^{10}$ One line of

U.S.C. $\S 77 \mathrm{k}(\mathrm{e})$ (1964), provides that plaintiffs in a section 11 or section 12 action may be required to post security for expenses. The 1934 Act has no such provision applying to rule 10b5. Finally, the venue provision in section 22(a) of the 1933 Act, 15 U.S.C. $\$ 77 v(a)$ (1964), is more restrictive than that in section 27 of the 1934 Act, 15 U.S.C. \& 78aa (1964).

Both section 11 and section 12(2) provide certain defenses. See notes 29-35 infra and accompanying text. In a procedural sense, however, the defenses simply shift the burden of proof as to the elements of scienter and negligence to the defendant, and are thus not "restrictions." The defenses are restrictive in that, without them, sections 11 and 12(2) would dispense with the elements of scienter and negligence altogether. In this regard, the defenses are not procedural but substantive restrictions. Failure to distinguish the procedural and substantive restrictions of the express provisions of the 1933 Act has led to considerable confusion in rule 10b-5 case law. See notes 16 \& 44 infra.

8. See Fischman v. Raytheon Mfg. Co., 188 F.2d 783 (2d Cir. 195I); Oshorne v. Mallory, 86 F. Supp. 869 (S.D.N.Y. 1949); Hawkins v. Merrill, Lynch, Pierce, Fenner \& Beane, 85 F. Supp. 104 (W.D. Ark. 1949). Contra, Rosenberg v. Globe Aircraft Corp., 80 F. Supp. 123 (E.D. Pa. 1948); Montague v. Electronics Corp., 76 F. Supp. 933 (S.D.N.Y. 1948).

Fischman has been criticized for ignoring section $12(2)$ in favor of rule $10 \mathrm{~b}-5$, even though section 12(2) was equally available to the plaintiff (buyer) in that case. See, e.g., Trussell v. United Underwriters, Ltd., 228 F. Supp. 757, 765 (1964). In some situations, however, a buyer is altogether precluded from bringing either a section 11 or a section 12(2) action. See notes 37-41 infra and accompanying text.

Rosenberg and Montague, the principal cases denying buyers a rule $10 \mathrm{~b} .5$ remedy, are discussed in notes $42-44$ infra. For a general discussion of the question whether a rule 10b-5 action can be brought when the claim could also be brought under the express provisions of the 1933 Act, see note 48 infra.

9. See, e.g., Jordan Bldg. Corp. v. Doyle, O'Connor \& Co., 401 F.2d 47 (7th Cir. 1968); Stevens v. Vowell, 343 F.2d 374 (10th Cir. 1965); Royal Air Props., lnc. v. Smith, 312 F.2d 210 (9th Cir. 1962); Boone v. Baugh, 308 F.2d 711 (8th Cir. 1962); Texas Continental Life Ins. Co. v. Dunne, 307 F.2d 242 (6th Cir. 1962); Ellis v. Carter, 29l F.2d 270 (9th Cir. 1961); Miller v. Bargain City, U.S.A., Inc., 229 F. Supp. 33 (E.D. Pa. 1964); Dauphin v. Redwall Corp., 201 F. Supp. 466 (D. Del. 1962). The propriety of the rule 10b-5 private remedy was questioned in Drake v. Thor Power Tool Co., 282 F. Supp. 94 (N.D. III. 1967), and Weber v. C.M.P. Corp., 242 F. Supp. 321 (S.D.N.Y. 1965), but a buyer's action was nevertheless allowed.

10. Professor Prosser lists the grounds for imposing tort liability under three headings: Intentional conduct, negligence, and strict-or "no fault"-liability. Prosser $\S 6$, at 27. The same division is adopted in RESTATEMENT (SECOND) OF TORTs (1965) (table of contents). Under sections 11 and 12(2) of the 1933 Act, plaintiff is required to prove only that defendant made an untrue statement or material omission in a registration statement or prospectus. Under section 
cases $^{11}$ emphasizes that rule $10 \mathrm{~b}-5$, as an antifraud provision, should be read to require a showing of scienter. ${ }^{12}$ Thus, whereas section 12(2) of the 1933 Act reaches negligent as well as intentional misconduct, ${ }^{13}$ a rule $10 \mathrm{~b}-5$ action would be restricted to cases of intentional misconduct. Not to make such a distinction, it is argued, would be to deny effect to the congressionally intended procedural restrictions of section $12(2) .{ }^{14} \mathrm{~A}$ second line of cases $^{15}$ has dispensed with the element

11 , the issuing corporation is strictly liable unless plaintiff knew that the statement was inaccurate, but all other defendants are permitted defenses limiting their liability to knowing or negligent conduct. Section 12(2) permits a similar defense. See text accompanying notes 28 \& 33 infra. Considerable confusion exists as to which grounds underlie rule $10 \mathrm{~b}-5$ liability. See notes $12,16 \& 17$ infra and accompanying text.

11. See, e.g., Weber v. C.M.P. Corp., 242 F. Supp. 321, 324 (S.D.N.Y. 1965); Trussell v. United Underwriters, Ltd., 228 F. Supp. 757, 770 (D. Colo. 1964); Thiele v. Shields, 131 F. Supp. 416, 419 (S.D.N.Y. 1955). See also 3 Loss 1766.

12. This distinction was suggested in Fischman v. Raytheon Mfg. Co., 188 F.2d 783 (2d Cir. 1951), in which the court stated that when the ingredient of fraud is added to conduct actionable under the $1933 \mathrm{Act}$, "that conduct becomes actionable under $\S 10(\mathrm{~b})$ of the 1934 Act and the Rule . . . whether or not [one] could maintain a suit under $\S 11$ of the 1933 Act." Id. at 787. Though Fischman is specifically concerned with section 11 of the 1933 Act, its reasoning applies to the distinction between rule $10 \mathrm{~b}-5$ and section $12(2)$ as well.

The common-law elements of fraud or deceit are: (1) A false representation of; (2) a material; (3) fact; (4) known by the defendant to be false but made for the purpose of inducing the plaintiff to rely on it, on which; (5) the plaintiff does justifiably rely; (6) to his detriment. 3 Loss 1431.

The term "scienter," with reference to the fourth element, is defined by some as "knowledge of the falsity of a representation"; by others as "intent to mislead." Compare 3 Loss 1431 will PROSSER \& 102, at 715.

The term "fraud" is afflicted with a similar ambiguity stemming from the fact that, while in its common-law sense "fraud" connoted all six of the elements above, including specific intent to defraud, Derry v. Peek, 14 App. Cas. 337 (1889), the term "has a broader meaning in equity ... and intention to defraud or to misrepresent is not a necessary element." SEC v. Capital Gains Research Bureau, 375 U.S. 180, 193 (1963), quoting W. DE FUnIAK, HaNDBOOK of MODERN EQUiTY 235 (2d ed. 1956). Under the fraud provisions of the 1933 and 1934 Acts, not only is the element of scienter being stripped of its common-law meaning, see Trussell v. United Underwriters, Ltd., 228 F. Supp. 757, 772 (D. Colo. 1964) (suggesting that "some element of scienter, albeit attenuated from common law deceit," be read into rule $10 \mathrm{~b}-5(2)$ ), but also the concept of fraud is being stripped of the element of scienter, both in actions for damages as well as in equitable proceedings. See note 17 infra. Thus, when a court deciding a securities case uses the term "fraud," it is not always clear whether a requirement of scienter is intended, sec note 45 infra, or, if it is intended, which definition of scienter is meant. See, for example, text accompanying notes 71-73 infra. At least one court has been accused of having "apparently used [the term 'defraud'] in its 'modern' scientific sense of 'do something bad to.'" R. JENnings \& H. Marsh, Securities Regulation, Cases and Materials 961 (2d ed. 1968) [hereinafter cited as JENNINGS \& MARSH].

13. For the text of section 12(2) see note 6 supra.

14. See, e.g., Trussell v. United Underwriters, Ltd., 228 F. Supp. 757, 770 (D. Colo. 1964).

15. See, e.g., Myzel v. Fields, 386 F.2d 718 (8th Cir. 1967), cert. denied, 390 U.S. 951 (1968); Stevens v. Vowell, 343 F.2d 374 (10th Cir. 1965); Royal Air Props., Inc. v. Smith, 312 F.2d 210 (9th Cir. 1962); Ellis v. Carter, 291 F.2d 270 (9th Cir. 1961); Wellington Computer 
of scienter in rule $10 \mathrm{~b}-5$ actions, emphasizing that the language of the rule, no less than the language of section $12(2)$, seems to cover negligent as well as intentional conduct. ${ }^{16}$ It is more important, according to this line of cases, to equalize as nearly as possible the remedies available to defrauded sellers and buyers than it is to "save" an express liability provision which would possibly retain its vitality even if a showing of scienter were no longer required in a rule $10 \mathrm{~b}-5$ action. ${ }^{17}$

Graphics, Inc. v. Modell, 315 F. Supp. 24 (S.D.N.Y. 1970); Kohler v. Kohler, 208 F. Supp. 808 (E.D. Wis. 1962), affd, 319 F.2d 634 (7th Cir. 1963).

16. See note 2 supra for the text of rule $10 \mathrm{~b}-5$. The literal language of at least the second and third clauses of the rule, it is argued, does not require a showing of actual fraud, but only a misstatement, material omission, or conduct which would operate as a fraud. The second clause, moreover, forbids misleading statements and omissions "in language almost identical to that of sections 11 and 12(2)." Folk, Civil Liabilities Under the Federal Securities Acts: the BarChris Case, Part II-the Broader Implications, 55 VA. L. REv. 199, 238 (1969) [hereinafter cited as Folk, Part IIJ. The difficulty with arguing from the literal language alone, however, is that the language of the second clause does not seem to require a showing of negligence either. The similar language in sections 11 and 12 (2) is limited by the defenses which are made available, see note 10 supra, but those defenses have no counterpart in rule $10 \mathrm{~b}-5$. The tripartite division of the rule seems to suggest a correlation with all three bases for imposing tort liability mentioned in note 10 supra. See Comment, Negligent Misrepresentations Under Rule 10b-5, 32 U. CH. L. REv. 824, 825-26 (1965). It has been suggested, however, that the failure to read into the second clause a requirement that the plaintiff prove negligence would go too far, in that rule $10 \mathrm{~b}-5$ would then preempt not just the procedural restrictions of section 12(2), but the express liability provisions of the 1933 Act as a whole. Folk, Part II 243 n.157. At least one authority has interpreted Ellis v. Carter, 291 F.2d 270 (9th Cir. 1961), and its companion cases as having done just that. See Jennings \& MARSh 867-68. But see Note, Proof of Scienter Necessary in a Private Suit Under SEC Anti-Fraud Rule 10b-5, 63 Mich. L. Rev. 1070, 1077 (1965), in which it is suggested that the Ellis court meant only that actual knowledge need not be proved, leaving open the possibility of a requirement that plaintiff prove defendant's negligent lack of knowledge. Actually, Ellis can be read either way, for when it chooses to permit buyers and sellers to sue under rule 10b-5 without distinction and without being subject to the "restrictions" of the express provisions of the 1933 Act, it uses the term "restriction" ambiguously. If the court was merely referring to the procedural restrictions enumerated in note 7 supra, then Ellis undoubtedly follows the weight of authority, since few courts have subjected buyers to the procedural restrictions of the 1933 Act. If, on the other hand, the court in Ellis meant to free rule $10 \mathrm{~b}-5$ of the substantive elements of scienter and negligence, both of which, as was pointed out in note 7 supra, are retained in the 1933 Act as alternative bases of liability, then Ellis clearly goes too far, since it is not yet even agreed that an action sounding in negligence can be maintained under rule $10 \mathrm{~b}-5$.

17. Professor Folk remarks that the "alarums sounded over rule 10b-5's tendency to swallow up all the express civil liability provisions of the 1933 and 1934 Acts are exaggerated and seem rather carping . . . " Folk, Part II 244. He advocates that a compromise be reached between the extreme of requiring a showing of scienter, see note 11 supra and accompanying text, and that of requiring only a showing of a misstatement or omission, see note 16 supra, by judicially importing a negligence standard into rule $10 \mathrm{~b}-5(2)$ and by placing the burden of proving negligence on the plaintiff. Folk, Part II 243-44. See generally Mann, Rule 10b-5: 
Regardless of the view which eventually prevails, ${ }^{18}$ two problems of construction will continue to confront the courts, one or both of which could survive the resolution of the controversy over the basis of tort liability under rule $10 \mathrm{~b}-5$. First, the courts must continue to grapple with the elusive element of scienter, as well as with the broader concept of fraud, of which scienter is but a part. ${ }^{19}$ Although scienter may no longer be a necessary condition for imposing rule $10 \mathrm{~b}-5$ liability, it will nevertheless remain a sufficient condition for imposing liability under the rule. ${ }^{20}$ Second, assuming the continued vitality of the rule $10 b-5$ action for negligence, the courts must spell out the nature of the duty imposed by the rule, the parties on whom the duty is imposed and to whom it is owed, and the extent to which rule 10b-5

Evolution of a Continuum of Conduct to Replace the Catch Phrases of Negligence and Scienter, 45 N.Y.U.L. REv. 1206 (1970). Section 12(2) and rule 10b-5 would thus be distinguishable as to the party bearing the burden of proof on the question of negligence, and a defrauded buyer would simply have two remedies: one which relieved him of the burden of proving negligence but which was subject to all of the procedural restrictions enumerated in note 7 supra; the other in which he bore the burden of proving negligence but was unencumbered by procedural restrictions.

Such an approach was foreshadowed in SEC v. Texas Gulf Sulphur Co., 401 F.2d 833, 855 (2d Cir. 1968), cert. denied, 394 U.S. 976 (1969), a suit to obtain injunctive relief under rule 10b5 , in which the court said that it was only necessary for the SEC to show "lack of diligence, constructive fraud, or unreasonable or negligent conduct." A similar approach was taken in Mutual Shares Corp. v. Genesco, 1nc., 384 F.2d 540, 547 (2d Cir. 1967), a suit for injunctive relief brought by a private party, but the court cited as authority SEC v. Capital Gains Research Bureau, Inc., 375 U.S. 180 (1963), which merely held that "[i]t is not necessary in a suit for equitable or prophylactic relief to establish all the elements required in a suit for monetary damages." Id. at 193. However, in Wellington Computer Graphics, Inc. v. Modell, 315 F. Supp. 24, 26 (S.D.N.Y. 1970), the district court indicated that the Texas Gulf Sulphur language was applicable in an action for damages as well. See also note 99 infra and accompanying tcxt.

18. Bromberg remarks that the trend is "very much against" requiring proof of scienter in rule 10b-5 actions. BROMBeRg $§ 2.6(1)$ at 50 . While this "trend" has been said to be largely in the eye of the beholder, JeNnings \& Marsh 866 n.6, Folk's willingness to assume that negligence will eventually be equated with "fraud" under rule 10b-5, see Folk, Part II 243, indicates more than one beholder in whose eye the trend appears. Undoubtedly the judicial trend is in the direction pointed by Bromberg and Folk. The judiciary, however, might be preempted by legislative re-examination of the 1933 and 1934 Acts, as was called for by the courts themselves in Barnes v. Osolsky, 373 F.2d 2E9, 273 (2d Cir. I j, and in Drake v. Thor Power Tool Co., 282 F. Supp. 94, 98 (N.D. 1ll. 1967). See also Cohen, Truth in Securities Revisited, 79 Harv. L. Rev. 1340 (1966); Henkel, Codification-Civil Liability Under the Federal Securities Laws, 22 Bus. Law. 866, 871 (1967); Sommer, Rule 10b-5: Notes for Legislation, 17 CASE W. RES. L. Rev. 1029 (1966).

19. See note 12 supra.

20. Although in many situations negligence can be established more easily than fraudulent intent, situations might arise in which the reverse is true. For example, when a defendant has gone through all the motions of exercising due care in the making of a statement but can be shown to have done so with foreknowledge that the statement will nevertheless be misleading, it might be impossible to establish negligence even though defendant's intent to defraud is clear. 
liability is to be distinguished in each of these respects from liability under the express provisions of the 1933 Act.

In light of the holding in Escott $v$. BarChris Construction Corp., ${ }^{21}$ the latter question takes on particular urgency with respect to potential rule 10b-5 liability for misrepresentations in a prospectus. BarChris delineated for the first time the standard of care for persons who are expressly subject to liability under section 11 of the 1933 Act ${ }^{22}$ and are desirous of taking advantage of the "due diligence" defenses provided by that section. ${ }^{23}$ Section 11 , of course, is to be distinguished from section 12(2) in that the former grants a right of action for misstatements or omissions in a registration statement, rather than for misstatements or omissions in a prospectus. ${ }^{24}$ And, as earlier discussed, it was section 12(2)'s grant of a right of action to a purchaser, not section 1 l's, that originally stimulated the courts to grant the seller a private right of action under rule $10 \mathrm{~b}-5 .{ }^{25}$ Yet, because the prospectus of a registered issue is a required part of the registration statement, ${ }^{26}$ considerable overlap in the coverage of the two sections of the 1933 Act exists. ${ }^{27}$ Further, with both sections

21. 283 F. Supp. 643 (S.D.N.Y. 1968).

22. For the persons liable under section II, see text accompanying note 32 infra.

23. Section II(b) provides all section II defendants except the issuing corporation itself-whose only defense under section II(a) is that plaintiff knew the registration statement was false-with certain defenses of non-involvement, non-negligence, and lack of scienter. BarChris was chielly concerned with the latter two defenses, which are spoken of as section Il's "due diligence" defenses. For a discussion of the specific defenses, see notes 29-32 infra and accompanying text. In addition to its function as a label for these specific defenses, the term "due diligence" has a generic meaning as well. While courts have generally agreed that "due diligene" and "due care" are practically synonymous, see, e.g., Hendricks v. Western Union Tel. Co., 126 N.C. 304, 312, 35 S.E. 543, 546 (1900); Western Union Tel. Co. v. Smith, 133 S.WV. 1062, 1064 (Tex. Civ. App. 1911), it is analytically useful to distinguish them. "Due care" can be said to be a standard of care for the carrying out of a voluntary act. One may omit doing the act, but if one chooses to act, one must act with due care. "Due diligence," on the other hand, connotes an affirmative duty to perform an act as well as to perform it carefully. Of course, "due care" in a generally voluntary course of conduct might entail specific duties of due diligence. Nevertheless, the two terms have different shadings of meaning and will be distinguished hereafter in this note. See, for example, note 34 infra and accompanying text.

24. See note l supra.

25. See text accompanying notes $5 \& 6$ supra.

26. The 1933 Act does not itself expressly state that the prospectus is a required part of the registration statement, but section 10, 15 U.S.C. $\$ 77 j(a)$ (1964), defines the information which must be contained in a prospectus by reference to the schedule of information required in a registration statement. See also SEC Reg. C, 17 C.F.R. \$ 230.404(a) (1970), which states, in part, that "a copy of the proposed prospectus may be filed as a part of the registration statement proper in lieu of furnishing the information in item-and-answer form."

27. See Folk, Part II 20I. The most important difference between the two sections, according to Folk, is the strict privity requirement of section 12(2), which permits a buyer to sue 
allowing for affirmative defenses in language sufficiently similar to connote a congressional intent that the standard of diligence should be the same in both sections, ${ }^{28}$ the delineation in BarChris of such a standard for persons subject to liability under section 11 could reasonably be said to have defined the standard of diligence for those subject to liability under section $12(2)$ as well.

The most important due diligence defense considered in BarChris concerns the "non-expertized" portions of the registration statement, ${ }^{29}$ as to which the section 11 defendant must show that he made a "reasonable investigation" 30 of the statements contained therein and that, as a result of such investigation, he had reasonable grounds to believe and did believe that the registration statement was true and that no material fact had been omitted. ${ }^{31}$ The duty of reasonable investigation is imposed on directors of the issuing corporation, other signers of the registration statement, and underwriters of the issue, and is owed to anyone who acquires the security being registered..$^{32}$ It is this section 11 duty to which section $12(2)$ 's duty to exercise reasonable care in the sale of a security by means of a prospectus or oral communication is most analogous. ${ }^{33}$ Even though a section 12(2) defendant does not have an explicit statutory obligation to make a reasonable investigation of the sort

only his immediate seller. Section 11 has no such requirement, but is restricted, on the other hand, to purchasers of registered securities, whereas section 12(2) is available to the purchaser of any security, whether registered or not. Rule $10 \mathrm{~b}-5$ is closer to section 11 on the malter of privity. See note 38 infra.

28. See Folk, Part II 207-16.

29. Non-expertized portions are those portions of the registration statement "not purporting to be made on the authority of an expert, and not purporting to be a copy of or extract from a report or valuation of an expert, and not purporting to be made on the authorily of a public offrcial . . . " 1933 Act $\S 11$ (a)(A), 15 U.S.C. § 77k(b)(3)(A) (1964).

30. The standard of reasonableness is defined as "that required of a prudent man in the management of his own property." Id. § 11 (c), 15 U.S.C. § $77 \mathrm{k}$ (c) (1964). The most important feature of BarChris's delineation of what constitutes a "reasonable investigation" was its requirement that a potential section 11 defendant verify information provided by the issuing corporation.

31. 15 U.S.C. § $77 \mathrm{k}(\mathrm{b})(3)(\mathrm{A})$ (1964). The other due diligence defenses provided by section $11(\mathrm{~b})(3)$ are concerned with: those "expertized" parts of the registration statement purporting to be made on the defendant's authority as an expert, as to which defendant's duty of care is much the same as it is for "non-expertized" portions of the statement; and those "expertized" parts purporting to be made on the authority of someone else as to which defendant only need show that there was no reasonable ground to believe, and he did not believe, that that part of the statement was false.

32. 1933 Act § II(a), 15 U.S.C. § 77k(a) (1964).

33. See Folk, Part II 207-16. 
required by section 11, an exercise of reasonable care under section 12(2) might sometimes entail such an investigation, ${ }^{34}$ including, in rare circumstances, a duty of verification of the kind which BarChris required of section 11 defendants. ${ }^{35}$ Thus, the problem of reconciling rule $10 \mathrm{~b}-5$ with section 11 is "essentially the same as that of reconciling it with section $12(2) . " 36$

The effect of BarChris on rule 10b-5 prospectus liability depends, as a practical matter, on whether rule $10 \mathrm{~b}-5$ provides any significant protection against negligent misstatements or omissions in a prospectus beyond that afforded by the express provisions of the 1933 Act. However, as of 1968, the year BarChris was decided, rule 10b-5 claims for damages based on a misleading prospectus had been allowed to stand in only two cases, both of which involved defendants who were alleged to have had a specific intent to defraud. Iri Fischman v. Raytheon Manufacturing Co ${ }^{37}$ a claim was allowed under rule $\mathrm{IOb}$ 5 where holders of unregistered common stock had been fraudulently induced to purchase by means of a misleading prospectus and registration statement for a simultaneous issue of registered preferred stock, but were unable to bring a section 11 action because they were not purchasers of the security described in the prospectus..$^{38}$ In Thiele v. Shields ${ }^{39}$ a claim was allowed under rule $10 \mathrm{~b}-5$ where a purchaser of municipal bonds was misled by an offering circular used in connection with an allegedly fraudulent scheme to sell the bonds. The purchaser was unable to state a claim under either of the express provisions of

34. Id. at 213. This is an illustration of how a duty of due care in a voluntary, general course of conduct might entail specific duties of diligence. See note 23 supra.

35. Folk, Part II 213.

36. JENNINGS \& MARSH 868.

37. 188 F.2d 783 (2d Cir. 1951).

38. On section 11 's limitation to purchasers of registered securities, see notes 1 \& 27 supra. For the criticism that Fischman failed to consider the applicability of section 12(2), see note 8 supra.

Section 12(2) requires privity between plaintiff and defendant. See note 27 supra. Because privity is not an element of common-law fraud, see note 12 supra, rule $10 \mathrm{~b}-5$ is not thought to require such a showing, see Texas Continental Life Ins. Co. v. Dunne, 307 F.2d 242, 249 (6th Cir. 1962); BRomberg § 8.5, at 205-08; Comment, Civil Liability Under Section IOb and Rule 10b-5: A Suggestion for Replacing the Doctrine of Privity, 74 YALE L.J. 659, 663 (1965), although one early opinion, no longer considered valid precedent, ruled to the contrary. Sce Joseph v. Farnesworth Radio \& Telev. Corp., 198 F.2d 883 (2d Cir. 1952). Thus, had plaintiffs in Fischman purchased common stock through an intermediate vendor, relying on the registration statement of the registered preferred stock, they could have maintained neither a section 11 nor a section $12(2)$ action.

39. 131 F. Supp. 416 (S.D.N.Y. 1955). 
the 1933 Act because issuers of municipal bonds are neither required to register them ${ }^{40}$ nor subject to liability under section $12(2) .^{41}$ In two earlier cases, ${ }^{42}$ in which plaintiffs' claims were actionable under section 11 , but were brought under rule $10 \mathrm{~b}-5$ in order to avoid the procedural restrictions of the express liability provision, ${ }^{43}$ the rule $10 b=5$ cause of action was either disallowed or subjected to the procedural restrictions of section $11 .^{44}$ At least two later cases involving a misleading prospectus have reiterated that in order to maintain an action under rule $10 b-5$, plaintiff must allege and prove fraudulent conduct. ${ }^{45}$

40. Municipal bonds are one of the securities exempted from the registration requirements of the 1933 Act. 15 U.S.C. $\S 77 c(a)(2)$ (1964).

41. Section 12(2) specifically exempts from liability issuers of those seeurities exempted from registration by section 3(a)(2) of the 1933 Act. See note 40 supra.

42. Rosenberg v. Globe Aircraft Corp., 80 F. Supp. 123 (E.D. Pa. 1948); Montague v. Electronics Corp., 76 F. Supp. 933 (S.D.N.Y. 1948).

43. In Montague plaintiff was attempting to avoid the security-for-expenses provisions of section 11. In Rosenberg plaintiff was attempting to avoid section 11's restrictive venue provisions. See note 7 supra.

44. The court in Montague specifically disallowed the rule $10 \mathrm{~b}-5$ claim; the court in Rosenberg, without deciding whether a rule $10 \mathrm{~b}-5$ claim was stated, held that in any event the venue provisions of sections 11 and 12(2) governed the action exclusively. This is one of the few examples of a court's having subjected the buyer under rule $10 \mathrm{~b}-5$ to the procedural restrictions of the 1933 Act. It does not necessarily follow, however, as Jennings and Marsh mainlain, that because Rosenberg would subject the buyer to the procedural restrictions of sections 11 and 12 enumerated in note 7 supra, his rule 10b-5 action would be subject to "all of the defenses and qualifications of a suit under Section 11 (which is the same thing as saying that it can't be maintained al all)." JENNINGS \& MARCH 868 (emphasis added). To be sure, if quite apart from Rosenberg, a negligence standard were to be read into lob-5(2), Rosenberg's addition of the procedural restrictions of the 1933 Act would do away with the rule 10b-5 remedy. Rosenberg itself, however, cannot be cited as authority for the proposition that the substantive elements contained in section 11's due diligence defenses are to be read into rule 10b-5, since Rosenberg merely imposed section 11 's procedural restrictions. For the effect of Fischman on Rosenberg and Montague, see note 48 infra.

45. Gould v. Tricon, Inc., 272 F. Supp. 385, 393 (S.D.N.Y. 1967); Colonial Realty Corp. v. Brunswick Corp., 257 F. Supp. 875, 882 (S.D.N.Y. 1966) (dictum). In Gould plaintifr's claims under section 12(2) were allowed to stand, but his rule 10b-5 claims were dismissed because fraud was not alleged. In Colonial Realty plaintiff was unable to state a claim under section II because he was not a "purchaser" within the meaning of that section, but the court did indicate that he might have a cause of action under rule $10 \mathrm{~b}-5$, if "fraud" could be shown. Predictably, each case seems to attach a different meaning to "fraud." Gould apparently assumes a showing of scienter is required, while Colonial Realty follows SEC v. Capital Gains Research Burcau, 375 U.S. 180 (1963), which dispenses with the element of scienter in cquilable proceedings. See note 17 supra. This can be explained by the faet that Gould is an action for damages, whlle Colonial Realty could be said to be suggesting that plaintiff bring an cquitable action. Confusion results, however, because Gould cites Colonial Realty as authority for the proposition that proof of fraud is required in a rule $10 \mathrm{~b}-5$ action. For a general discussion of "fraud," see note 12 supra.

Texas Continental Life Ins. Co. v. Bankers Bond Co., 187 F. Supp. 14 (W.D. Ky. 1960), 
The paucity of early rule $10 \mathrm{~b}-5$ cases. involving misstatements or omissions in a selling device such as a prospectus can be explained in part by the once-held view that the sole protection afforded by rule $10 \mathrm{~b}-5$ was against the misrepresentations of a buyer ${ }^{46}$ and in part by the early proscription against applying rule $10 \mathrm{~b}-5$ when express provisions of the 1933 Act are also applicable. ${ }^{47}$ But even after Fischman apparently eliminated both of these obstacles ${ }^{48}$ few rule $10 \mathrm{~b}-5$ cases involving a prospectus were litigated. This curious inertia in an otherwise burgeoning period in rule $10 \mathrm{~b}-5$ 's development as a civil remedy for investors was undoubtedly due to the notion spawned in Fischman that rule 10b-5 reached only intentional conduct. As to

rev'd on fact issue sub nom. Texas Continental Life Ins. Co. v. Dunne, 307 F.2d 242 (6th Cir. 1962), which held that a plaintiff purchaser "need only prove that a statement in a prospectus or oral communication is in fact false," $187 \mathrm{~F}$. Supp. at 23, is distinguishable-plaintiff only sought equitable relief, see notes 12 \& 17 supra-and based on dubious authority. The court cited two cases in support of its holding: Thiele, which, of course, stands for just the opposite proposition, and Ouachita Indus., Inc. v. Willingham, 179 F. Supp. 493 (W.D. Ark. 1959), which is a section 12(2), rather than a rule 10b-5 action. The court of appeals, while reversing on other grounds, suggests that intent to defraud is material and was proven in this case. $307 \mathrm{~F} .2 \mathrm{~d}$ at 249 .

46. Obviously, a buyer is unlikely to have made his misrepresentations in a selling device.

47. Both the proscription against applying rule $10 \mathrm{~b}-5$ when an express provision of the 1933 Act is also applicable and the limitation of rule $10 \mathrm{~b}-5$ as a seller's remedy are ultimately traceable to Montague v. Electronic Corp., 76 F. Supp. 933 (S.D.N.Y. 1948). See note 48 infra.

48. Largely because of Fischman, it has been said of Montague and Rosenberg that they "cannot longer be regarded as valid," at least insofar as they hold that a buyer is altogether barred from bringing an action under rule 10b-5. Bromberg $\$ 2.4(2)$, at 34 n.76. Montague, however, also stands for the more limited principle that a buyer's claim under rule $10 \mathrm{~b}-5$ will be dismissed when it could also be stated under one of the express provisions of the 1933 Act. Technically, the holding in Fischman left this principle intact with respect to section $\mathbb{U}$ of the 1933 Act, since the rule 10b-5 plaintiff in Fischman could not bring an action under section 11 . See note 38 supra and accompanying text. But by overlooking section 12(2)'s applicability, see note 8 supra, Fischman seemed to invalidate the Montague principle as applied to section 12(2). Moreover, in dictum at least, the court in Fischman rejected the Montague principle even as applied to section 11. 188 F.2d at 787. See note 12 supra. See also Osborne v. Mallory, 86 F. Supp. 869, 879 (S.D.N.Y. 1949), where it is stated that "[c]oncurrent remedies under several sections of both Acts may be available to the investor injured by the seller's fraudulent practices."

The court in Jordon Bldg. Corp. v. Doyle, O'Connor \& Co., 282 F. Supp. 87 (N.D. III. 1967), attempted to revive the broader implication of Montague that a buyer cannot maintain an action under rule 10b-5, but Jordon was reversed on appeal. $401 \mathrm{~F} .2 \mathrm{~d} 47$ (7th Cir. 1968). At least two rccent cases have adhered to the more limited Montague principle that conflicts between the express provisions of the 1933 Act and the implied private remedy under rule 10b-5 should be resolved in favor of the Act. See Gilbert v. Nixon, 429 F.2d 348, 355 (10th Cir. 1970); Drake v. Thor Power Tool Co., 282 F. Supp. 94, 99-102 (N.D. Ill. 1967). However, both cases Here concerned with section 12(2). The Fischnan dictum quoted in note 12 supra has never been explicitly rejected by later courts. 
that kind of conduct, the registration and civil liability provisions of the 1933 Act apparently were having such a prophylactic effect that even section 11 was seldom invoked to reach it..$^{49}$ Nevertheless, Fischman and Thiele demonstrate that rule $10 \mathrm{~b}-5$ provides significant protection beyond that provided by the express provisions of the 1933 Act_against misstatements or omissions in a prospectus-namely in cases involving the fraudulent sale of government or bank securities or the fraudulent use of a prospectus to induce the purchase or sale of a security other than the one described in the prospectus. The emergence of a rule $10 \mathrm{~b}-5$ right of action for merely negligent-perhaps even merely inadvertent-misstatements or omissions, ${ }^{50}$ together with the delineation in BarChris of the duty of diligence owed in the preparation of a prospectus, presages the possible extension of rule 10b-5 into the formerly neglected area of prospectus liability. The degree to which this extension will occur depends on the extent to which the duty of diligence owed under section 11 of the 1933 Act is found to be owed under rule $10 b-5$ as well.

Two provisions in the Securities and Exchange Act of 1934 provide a possible basis for distinguishing the duties imposed by section 11 and rule $10 \mathrm{~b}-5$. Section 10 (b) of the 1934 Act, ${ }^{51}$ which is the immediate source of the Commission's power to promulgate rule $10 \mathrm{~b}$ 5 , makes it unlawful to use or employ, in connection with the purchase or sale of a security, any manipulative or deceptive device in contravention of such rules as the Commission might prescribe..$^{52}$ Since rule $10 b-5$ can only implement and not add to section $10(\mathrm{~b}),{ }^{53}$ it might be argued that to hold a signer of a prospectus liable under rule $10 \mathrm{~b}-5$, the plaintiff must prove not only that the prospectus contained a misstatement or omission, as is sufficient for liability under section

\footnotetext{
49. Professor Loss remarked in 1961 that, while at the time it was passed, section 11 was considered to be the "bete noir which was going to stifle legitimate financing," it had actually produced only two reported recoveries in 28 years. 3 Loss 172I. The delineation in BarChris of the duty of diligence owed under section 11 has revived much of the original foreboding as to section II's effect on the securities industry. See generally Folk, Civil Liabifities Under the Federal Securities Acts: the BarChris Case, PartI, 55 VA. L. REv. 1, 3-4 (1969) thereinafter cited as Folk, Part I].

50. See notes 15-17 supra and accompanying text.

SI. 15 U.S.C. \& 78j(b) (1964).

52. See notes $15-17$ supra and accompanying text.

51. 15 U.S.C. $\& 78 \mathrm{j}(b)(1964)$.

52. For the text of section 10(b) of the 1934 Act, see note 2 supra.

53. Cf. 3 Loss 1765; Annot., 37 A.L.R.2d 649 (1954).
} 
11 of the 1933 Act, ${ }^{54}$ but also that the signer was actually involved in using the prospectus "in connection with" the purchase or sale of a security. ${ }^{55}$ The only exception to the requirement of actual involvement is that of section 20(a) of the 1934 Act, ${ }^{56}$ under which a person "controlling" 57 a violator of section $10(\mathrm{~b})$ or the rules promulgated thereunder would be jointly liable with such controlled person unless the controlling person acted in good faith and did not, directly or indirectly, induce the "act or acts constituting the violation or cause of action." ${ }^{58}$ Under the analogous provision of the 1933 Act, ${ }^{59}$ which applies to persons controlling a violator of section 11 or 12 of that act, the controlling person can avoid liability only by showing both that he had no actual knowledge and that he had no reasonable ground to believe that the prospectus or registration statement contained misstatements or omissions. Thus, a controlling person under the 1933 Act, like the person controlled, is under a duty to act reasonably on the basis of what he knows or could have known about the prospectus or registration statement, regardless whether he had any connection with its drafting or use. The liability of a controlling person under the 1934 Act, on the other hand, would appear to depend either on an inference of actual knowledge from which a further inference of a lack of good faith can be drawn, or on evidence that the controlling person directly or indirectly induced the employment of the misleading prospectus or registration statement.

54. See text accompanying notes $29-32$ supra. Such a showing would also be sufficient under rule $10 \mathrm{~b}-5(2)$, reading the clause literally. For the text of $10 \mathrm{~b}-5(2)$, see note 2 supra. Rule $10 \mathrm{~b}-$ $S(2)$ 's similarity to sections 11 and $12(2)$ is pointed out in note 16 supra.

55. Similarly, the language of the first and third clauses of the rule itself suggests a "use" requirement. See note 2 supra. A distinction between making a statement and using it deceptively is only meaningful with respect to a prospectus or other non-personal written documents, since in oral or written personal communications the "making" and the "use" occur simultaneously. That this distinction has not been pointed out before is perhaps explained by the paucity of rule $10 \mathrm{~b}-5$ cases dealing with a misleading prospectus. See text following note 36 supra. For the current interpretation of the phrase "in connection with," see note 86 infra.

56. 15 U.S.C. \& 78t(a) (1964).

57. For a discussion of what constitutes "control," see note 100 infra and accompanying text.

58. 15 U.S.C. § 78t(a) (1964). Because the controlling person must show non-inducement of the "acts constituting a violation or cause of action," his defense in a rule $10 \mathrm{~b} .5$ action depends on a prior determination of what constitutes a rule 10b-5 cause of action. Thus, by itself, section 20 adds little meaning to the language of section $10(\mathrm{~b})$ or rule $10 \mathrm{~b}-5$. The section is of service in distinguishing rule 10b-5 and section 11 of the 1933 Act, however, as the comparison in the text following this note between its language and the language of the "controlling person" provision of the 1933 Act indicates.

59. Section 1S, 15 U.S.C. § 770 (1964). 
Beyond these bare suggestions as to the difference between the duty imposed by rule $10 \mathrm{~b}-5$ and that imposed by section 11 of the 1933 Act, however, the 1934 Act is silent. Thus, just as the availability of a rule $10 \mathrm{~b}-5$ action itself depended on judicial inference, so the precise nature of the duty imposed by the rule, including an indication of the parties on whom the duty is imposed and those to whom it is owed, would seem to depend on judicial determination.

The recently decided case of Lanza $v$. Drexel \& $C 0 .{ }^{60}$ provides a unique opportunity for a post-BarChris comparison between the duty imposed by section 11 of the 1933 Act, and that imposed by rule 10b. 5 for misstatements or omissions in a prospectus. Lanza is a rule $10 \mathrm{~b}$ 5 case involving the same prospectus and many of the same defendants as were involved in BarChris. During the latter stages of what the court described as the "metoric growth and demise"61 of BarChris Construction Company, the officers of the corporation had arranged for the sale of debentures in order to alleviate an increasingly tight cash situation. The prospectus prepared in connection with the debenture issue contained misstatements and omissions which became the basis of the section 11 liability in BarChris. This same prospectus was given to representatives of Victor Billiard Company during negotiations leading to an exchange of common stock by which BarChris gained control of Victor Billiard. After purchasers of the debentures brought their section 11 action, BarChris promptly went into bankruptcy. The officers of Victor Billiard regained control of their company's stock at considerable expense to themselves and sought by way of various theories of tort liability to recover damages against the lead underwriter of the debentures issue ${ }^{62}$ and certain former directors of BarChris Corporation. Five of the directors named as defendants in Lanza had signed the prospectus and consequently had been held liable in BarChris under section 11 of the

60. CCH FED. SEC. L. REP. If 92,826 (S.D.N.Y. 1970).

61. Id. at 90,091 .

62. The lead underwriter was Drexel \& Company. Drexel was sued on grounds of respondeat superior, due to the position of its attorney and one of its members as directors of BarChris Construction Corporation. See note 63 infra and text accompanying note 67 infra. As lead underwriter of the debentures issue, Drexel was, of course, directly liable in BarChris under section 11. 283 F. Supp. at 692. See also Comment, The Expanding Liability of Securlties Underwriters: from BarChris to Globus, 1969 DukE L.J. 1191. The plaintiffs' omission of Drexel \& Company as a rule 10b-5 defendant in Lanza indicates the plaintiffs' doubts that an underwriter could, in normal circumstances, be considered to have "made" the misleading statements in the prospectus or to have "employed" it deceptively for purposes of rule 10b-5, even though it may have failed to make a section $1 \mathrm{i}$ reasonable investigation. 
1933 Act. ${ }^{63}$ It was against these five signers of the prospectus that Victor Billiard's officers made their rule 10b-5 claims. Of the five signers, only Kircher, the treasurer and chief financial officer, was actively involved in presenting the misleading prospectus to the negotiators for Victor Billiard. ${ }^{64}$ Of the three remaining inside directors, Russo, a vice-president and chief executive officer of the corporation, actively participated in the preparation of the prospectus but had no part in the negotiations with Victor Billiard, ${ }^{65}$ while the two remaining insiders, Vitolo and Pugliese, took no active part in either the drafting of the prospectus or its presentation to the plaintiffs and, at best, only suspected that the prospectus was misleading. ${ }^{66}$ Coleman, a director by virtue of his position with Drexel and Company and the one outside director named as a defendant in Lanza, had been held liable in BarChris only because he failed to make a sufficiently thorough investigation of the accuracy of the prospectus to meet the requirements of section 11 of the 1933 Act. ${ }^{67}$ There was no evidence that he suspected that the prospectus was false.

63. A sixth director, an attorney for the lead underwriter, who was not on the board when the misleading registration statement was filed, and was thus neither a signer for section 11 purposes nor a maker of an untrue statement for rule 10b-5 purposes, was charged in Lanza with conspiracy to continue a pattern of deception and concealment. He was absolved of liability. CCH FED. SEC. L. REP. II 92,826, at 90,100-01.

64. See id. at $90,094,90,103$.

65. Id. at 90,103 . When the extent of his role in the activities which became the cause of action in the BarChris case is considered, see 283 F. Supp. 643, 653, 661, 671, 676, 677 (1968), Russo's relative non-involvement in the negotiations with Victor Billiard Company hardly seems surprising.

66. In BarChris the court had found that even though they may not have read it, neither Vitolo nor Pugliese could have believed that the registration statement was wholly true. $283 \mathrm{~F}$. Supp. at 684-85. This finding was not cricial to the court's holding in BarChris, however, inasmuch as the court goes on to say that "in any case, there is nothing to show that they made any investigation of anything which they may not have known about or, understood." Id. at 685. In Lanza, on the other hand, while the court found that there were false statements of which Vitolo was aware, see CCH FED. SEC. L. REP. If 92,826, at 90,102, it found that Pugliese did not have any suspicion that the prospectus was partly false or misleading. Id. at 90,103 . There was no evidence in either BarChris or Lanza that either Vitolo or Pugliese took any active part in the actual deception of the plaintiffs in either case, and in Lanza the court seemed to equivocate on whether Vitolo knew that the prospectus was being used in the negotiations with Victor Billiard. See text accompanying notes 88-9l infra.

67. $283 \mathrm{~F}$. Supp. at 692-97. This is not to say that Coleman made no investigation at all. To the contrary, both he and Drexel's attorney made general investigations of the corporation prior to agreeing to underwrite the offering. They even directed specific inquiries to the inside directors about various parts of the registration statement. But they did not make an independent investigation of the accuracy of the answers they received. These inquiries were not sufficient for section 11 purposes, according to the court in BarChris. Id. 
Nor was there any evidence beyond the bare misstatements themselves that the other defendants were pursuing a common plan to defraud.

The fact situation in Lanza is thus similar to that in Fischman in the sense that a misleading prospectus was used in the sale of securities other than those described in the prospectus; ${ }^{68}$ but Lanza is, nevertheless, distinguishable from Fischman. Fischman not only predated the line of rule $10 \mathrm{~b}-5$ cases dispensing with the element of scienter ${ }^{69}$ but also dealt only with allegations of a specific intent to defraud. The court in Lanza, on the other hand, aware of both the newer line of $10 \mathrm{~b}-5$ cases and the newly delineated duty of diligence under section 11 of the 1933 Act, was faced with at least one defendant who was found not to have known either of the falsity of the prospectus which he signed or of its deceptive use, but who would have known at least of its falsity had he conducted the investigation required by section $11 .^{70}$ Moreover, the "scienter" of those defendants in Lanza who clearly did have knowledge of some sort, ranged from knowing use of a misleading prospectus, ${ }^{71}$ through knowing preparation of misleading statements in a prospectus, ${ }^{72}$ to mere suspicion of the falsity of a prospectus which one has signed. ${ }^{73}$ The court in Lanza was thus faced with two questions which the court in Fischman did not confront: namely, whether, absent a showing of scienter, liability could be imposed under rule $10 b-5$ on one who signed a prospectus without making a reasonable investigation of its contents; and whether, assuming that scienter was a required element of proof in a rule 10b-5 action, mere suspicion of the falsity of a prospectus, without any involvement in a common plan to defraud, or even any involvement in the preparation of the prospectus, is a sufficient showing of scienter to impose rule $10 \mathrm{~b}-5$ liability on a signer of the prospectus. ${ }^{74}$

68. See notes $37-38$ supra and accompanying text.

69. Indeed, Fischman is considered the originator of the view that scienter is a rcquircd element in a rule 10b-5 action. See note 12 supra.

70. Coleman and, according to the Lanza court at least, Pugliese could be so described. But see note 66 supra.

71. See text accompanying note 64 supra and accompanying notes $81-83$ infra describing Kircher's role in the deception.

72. See text accompanying note 65 supra and accompanying notes $84-85$ infra describing Russo's role in the deception.

73. Vitolo, and according to the findings in BarChris, Pugliese had such suspicions. But sce note 66 supra.

74. For a general discussion of the meaning of "scienter" and the related term "fraud," see note 12 supra. 
The court in Lanza found Kircher, Russo, and Vitolo to be liable under rule 10b-5, but absolved Pugliese and Coleman of liability. ${ }^{75} \mathrm{In}$ so doing, however, the court attempted to avoid having to choose between the line of cases holding that scienter is a required element of a rule $10 \mathrm{~b}-5$ action $^{76}$ and the line of cases dispensing with it. ${ }^{27}$ The court did so by finding that the defendants who were held liable had sufficient scienter to justify liability under the line of cases which required it, while finding that none of the defendants absolved of liability were sufficiently negligent to justify liability even under the line of cases dispensing with scienter. In its pre-occupation with avoiding the controversy regarding the requirement of scienter, the court never bothered to spell out what constitutes "scienter" when the defendant possibly knew of the falsity of a statement in a corporate document without knowing of the particular deception carried out. ${ }^{78}$ Nor did the court spell out the nature of the duty imposed by rule IOb5 , except to say that the section 11 standard of diligence is not incorporated in the rule. ${ }^{79}$ Thus, the questions raised by the factual situation in $L a n z a^{80}$ are not explicitly answered in that court's opinion. The answering of these questions requires careful examination of the Lanza court's specific findings with respect to each individual defendant.

The court itself observed that there were "gradations" 81 of culpability among those held liable. Kircher, described as a "highly intelligent and learned accountant," was said to know better than anyone that the prospectus was misleading. ${ }^{82}$ Because, as the chief negotiator for BarChris in the Victor Billiard transaction, he had personally given a copy of the prospectus to Victor Billiard's negotiator, he had clearly used the prospectus as a deceptive device in connection with the purchase and sale of securities and thereby met

75. CCH FED. SEC. L. REP. If 92,826, at 90,107.

76. See note II supra.

77. See note 15 supra.

7S. This is more than a distinction betwcen "knowledge of falsity" and "intent to deceive." See note 12 supra. The concern is rather with the distinction between making a false statement in writing (or knowing that a statement in writing is false) and knowing that the false statement is being used deceptively by another. This was arguably the case with Vitolo. See text accompanying notes $88-91$ infra.

79. CCH FED. SEC. L. REP. II 92,826, at 90,015, quoted in text accompanying note 111 infra.

80. See text accompanying note 74 supra.

81. CCH FED. SEC. L. REP. If 92,826, at 90,103.

82. Id. 
the "use" requirement of section $10(\mathrm{~b})$ and rule $10 \mathrm{~b}-5$ discussed earlier. 83

Russo personally prepared a grossly misleading backlog figure appearing in the prosectus, and the court found that if he "did not in fact know that the figure was overstated, he was so reckless in its preparation that his 10b-5 liability cannot be questioned." ${ }^{34}$ Yet the court did not find that Russo participated in, or even knew of, Kircher's deceptive employment of the prospectus in the negotiations with Victor Billiard. ${ }^{85}$ Taking the court's findings at face value, one might conclude that Russo's liability was based solely on his reckless preparation of the backlog figure and that a showing of one's participation in, or knowledge of, the deceptive employment of the prospectus is therefore not necessary under rule $10 \mathrm{~b}-5$. But this interpretation is unacceptable, not only because it is analytically unsound, ${ }^{86}$ but also because it ignores the limiting language of the statute pursuant to which rule $10 \mathrm{~b}-5$ was promulgated. ${ }^{87}$ Two further interpretations of the imposition of liability in Russo's case are possible, however, if one goes beyond the explicit language of the Lanza opinion. The imposition of liability might be said to imply a finding that, because of Russo's position of responsibility in the corporation and his active participation in the preparation of the

83. See notes $51-55$ supra and accompanying text.

84. CCH Fed. SEC. L. Rep. If 92,826, at 90,103.

85. See note 65 supra and accompanying text.

86. Under rule $10 \mathrm{~b}-5$ it is unlawful to make untrue statements "in connection with" the purchase or sale of a security. See text of rule $10 \mathrm{~b}-5$ in note 2 supra. There is, of course, no requirement of privity under the rule. See note 38 supra. Moreover, in SEC v. Texas Gulf Sulphur Co., 401 F.2d 833 (2d Cir. 1968), an injunctive proceeding involving a public release which omitted pertinent information of interest to the investing public, the court gave a broad interpretation of the phrase "in connection with," holding that in equitable procecdings, at least, rule $10 \mathrm{~b}-5$ is violated "whenever assertions are made . . . in a manner reasonably calculated to influence the investing public ... if such assertions are false or misleading or are so incomplete as to mislead irrespective of whether the issuance of the release was motivatcd by corporate officials for ulterior purposes." Id. at 862 . But as this language itself suggests, the court's conclusion was premised on its earlier holding in the same case that in an equitable proceeding it is only necessary to show defendant's lack of diligence, constructive fraud, or unreasonable or negligent conduct. See note 17 supra. If the Lanza court is to be taken at its word that the liability of the defendants in Lanza is based solely on intentional or reckless conduct, see text following note 77 supra, then the court must at least find that Russo knew of or recklessly disregarded the deceptive use of the prospectus as well as having recklessly prepared the figures in the prospectus. Otherwise his liability as a drafter would be based on conduct more negligent than knowing.

87. As was indicated in the text accompanying notes $51-55$ supra, section $10(b)$ seems to require that one participate in the employment of the device. 
prospectus, he must have either recklessly.ignored, or had actual knowledge of Kircher's utilization of the prospectus in the negotiations with plaintiff. Equally possible, however, is the implication that Russo was held by the court to have had a duty to guard against Kircher's utilization of the prospectus, quite apart from what he might actually have known. The court's silence as to which route it traveled in linking Russo to the deceptive use of the misleading prospectus seems to suggest that the court did not consider the matter but would be willing to arrive at liability by either route. That impression is buttressed by the fact that the same ambiguity occurs in the court's findings as to Vitolo, whose actual knowledge was even less apparent from the evidence.

The court suggests that despite his limited education and his nonparticipation in the drafting or deceptive employment of the prospectus, Vitolo, as president of BarChris, "owed duties of diligence ... to make sure that all official documents of the corporation were accurate ..." Vitolo's liability is not based merely on a lack of diligence, however, since, "[g]iven the extent and character of what he knew, [Vitolo] is found to have been a knowing party to the deception of the plaintiffs." 89 Yet the court's description of the extent of Vitolo's knowledge includes only his knowledge of false statements in the prospectus. As to Vitolo's link with Kircher's deceptive use of the prospectus, the court simply remarks, apparently responding to a defense of ignorance raised by Vitolo, that he "cannot be heard to say that he did not know that plaintiffs had received these documents; . . . he knew that, at a time when these were the most current documents showing the financial situation of the corporation, BarChris' representatives were negotiating with the plaintiffs ."90 Here, as with Russo, the court's remark could be construed either as a finding of fact that Vitolo must have had actual knowledge of the deceptive use of the prospectus ${ }^{91}$ or as a conclusion of law that Vitolo owed plaintiffs a duty of diligence.

Despite the court's failure to explain fully the basis of the liability of either Russo or Vitolo, it seems that the court reached the correct result with respect to both of these directors. Even if scienter is

88. CCH FED. SEC. L. REP. I 92,826 , at 90,102 .

89. Id.

90. Id.

91. Later language in the Lanza opinion indicates Vitolo may not have known of Kircher's sse of the prospectus in the negotiations. See note 94 infra. 
assumed to be a necessary element, and Vitolo and Russo are assumed not to have known that Kircher used the prospectus in the negotiations, each was a controlling person responsible for Kircher's actions. ${ }^{92}$ Regardless whether Russo could be said to have acted in good faith with respect to Victor Billiard Company, ${ }^{93}$ he had indirectly induced the act violating rule $10 \mathrm{~b}-5$ by preparing the misleading backlog figure. Likewise, regardless whether Vitolo could be said to have induced the use of the prospectus, his claim of good faith was insufficient since he allowed Kircher, whom he knew to be responsible for many of the misleading statements in the prospectus, to negotiate for BarChris. ${ }^{94}$ Indeed, the finding that Vitolo and Russo were liable due to their control of a violator of rule 10b-5 explains why the discussion of their own rule 10b-5 liability is so truncated. The crucial determinant of Russo's and Vitolo's liability, whether based on rule 10b-5 or section 20 of the 1934 Act, seems to have been their status as inside directors in the corporation. The court apparently felt that either an actual knowledge of, a duty to be familiar with, or a high degree of control over misstatements made in a prospectus or in personal negotiations ${ }^{95}$ could be inferred from one's very status as an insider and that any one of these inferences was a sufficient basis for liability. Since all three inferences could legitimately be drawn with respect to Russo and Vitolo, the court's failure to state which inference it would adjudge the most compelling is of little significance. The important question is whether these inferences are always to be

92. CCH FED. SEC. L. REP. If 92,826, at 90,103.

93. Under section 20 one must have acted in good faith and not have induced, dircetly or indirectly, any acts constituting a cause of action under the rule. See notes 56-59 supra and accompanying text. Knowingly drafting a misleading prospectus would be an indirect inducement of its deceptive use, whether or not one could be said to have acted in good faith with respect to the particular person deceived.

94. CCH FED. SEC. L. REP. If 92,826, at 90,103. It is significant that Vitolo's lack of good faith as a controlling person is based on what he is said to have known of Kircher and the prospectus, rather than what he is said to have known of the actual conduct of the negotiations. The court conspicuously avoids finding that Vitolo knew the plaintiffs had received a copy of the misleading prospectus, when such a finding would be quite appropriate.

95. Similarly, Folk says of inside directors defending in a section 11 action:

. . . the scope and depth of their knowledge of internal corporate affairs, or at least their continuing access to information, heighten their responsibilities [so that] in some instances, as in BarChris, no amount of investigation would afford protection or establish a "reasonable ground for belief" in a registration statement which in fact is false and misleading.

Folk, Part I 73. That an insider's knowledge is a rebuttable presumption under either section 11 or rule $10 \mathrm{~b}-5$ is suggested in note $10 \mathrm{I}$ infra and accompanying text. 
drawn in the case of an inside director and whether they are also to be drawn in the case of an outside director. The court implicitly speaks to each of these questions in giving its reasons for absolving Pugliese and Coleman of liability.

Of Pugliese, the court said that despite his title as vice-president, he was "genuinely ignorant of most of the things that concern us and unequipped by education or experience to understand them."96 His duties in the corporation, moreover, were said to be limited to the supervision of construction. ${ }^{97}$ The court found that if Pugliese read the registration statement at all, he did not understand it or suspect that it was misleading. ${ }^{98}$ His liability, therefore, could not be predicated on scienter. Nevertheless, the court went on to consider whether Pugliese could be held liable on some other ground. It concluded, however, that there must be at least a showing of a lack of due diligence, constructive fraud, or unreasonable or negligent conduct, ${ }^{99}$ and that there was no basis for so characterizing Pugliese's conduct. Similarly, Pugliese was found not to be liable as a controlling person because he "did nothing to induce any of the acts of the negotiators or of the draftsmen of the documents supplied to the plaintiffs . . . [and] acted in good faith at all times." 100

Thus, one's status as an insider, by itself, apparently will not support the inference that one must have known or that one had a duty to determine the accuracy of a prospectus which one signed or the uses to which the prospectus was being put, if one's capacity to understand the prospectus and one's responsibilities in the corporation are sufficiently limited. In these circumstances there must be an actual showing of the particular insider's negligence or lack of due diligence. ${ }^{101}$ While the court does not say what would be a

\footnotetext{
96. CCH FED. SEC. L. REP. If 92,826 , at 90,103 .

97. Id. at 90,104 .

98. Id. at 90,103 .

99. The Lanza court relied on SEC v. Texas Gulf Sulphur Co., 401 F.2d 833, 855 (2d Cir. 1968), for this language. For the significance of that reliance, see note 17 supra.

100. CCH Fed. SEC. L. Rep. If 92,826, at 90,104. The court did raise the question of whether "mere formal control" would be sufficient under section 20 of the 1934 Act. CCH FED. SEC. L. ReP. I 92,826, at 90,104 n.17. But it noted approvingly that at least one court had assumed that a director is by definition a controlling person. Moerman y. Zipco, Inc., $302 \mathrm{~F}$. Supp. 439, 447 (E.D.N.Y. 1969), aff d per curiam, 422 F.2d 871 (2d Cir. 1970), although it was unnecessary to decide the question in Lanza since, even assuming Pugliese was a controlling person, he was found to be free of liability.

101. Similarly, Folk says that in BarChris:

It is implied that the scope of an individual inside director's duties may be relevant to a court's refusing to find that it would be impossible . . . for him to have reasonable
} 
sufficient ground for characterizing Pugliese's conduct as negligent or lacking in diligence, it is clear from the court's finding of nonliability, that merely signing a prospectus without making the reasonable investigation required by section 11 is not sufficient in itself. If rule 10b-5 imposes any duty to know of the accuracy of a prospectus one has signed, it is apparently imposed only on those signers who are either in a corporate position responsible for the supervision of, or are actually engaged in the preparation or deceptive use of the prospectus. The particular duty imposed on this class of signers, moreover, appears to depend on whether the duty arises from what one was inferred to know or from what one was said to be responsible for knowing. If actual knowledge or reckless disregard of the inaccuracies in a prospectus can be inferred, then the signer could be said to owe a duty of diligence to prevent the deceptive employment of the prospectus, ${ }^{102}$ even if he has played no part in its preparation or employment. ${ }^{103}$ Conversely, it would seem to follow that if a signer takes a direct hand in the preparation or employment of the prospectus or is in a position to supervise same, then he is under a duty to determine its accuracy, whether or not he knew the prospectus to be false. ${ }^{104}$

That this characterization of the duty of diligence imposed by rule $10 \mathrm{~b}-5$ is indeed what the Lanza court intended, and that it consequently limits the liability of outside directors in much the same way that it limits the liability of insiders with limited responsibilities in the corporation, is indicated by the court's finding with respect to Coleman, the other defendant absolved of liability. The plaintiffs'

grounds for belief and actual belief in the accuracy of the prospectus. Thus, an individual with a narrow compass of duties or less chance to know the corporate affairs would probabiy be protected if he made a reasonable investigation but failed to turn up some misstatements. . . . These are fine distinctions, however, and a heavy burden still remains on the defendant to dispel a natural inference of probable knowledge.

Foik, Part I 23. Pugliese was found liable in BarChris because he made no investigation at all. See note 66 supra. Thus, he could only have been relieved of liability in Lanza because, due to his lack of actual knowledge of, or participatin in the deception practiced on the plaintiffs, he was under no duty of diligence. It cannot be said that he had met his rule 10b-5 duty of diligence because he had done nothing.

102. Russo and Vitolo could be said to have owed this duty. See text accompanying note 91 supra.

103. Vitolo's case could be so described. See text accompanying note 88 supra.

104. This case was not presented in Lanza but the result can be inferred from the court's findings with respect to Coleman. See text accompanying note 105 infra. Just as a duty to advise follows from one's knowledge of the falsity of the prospectus, so a duty to investigate follows from one's participation in the negotiations. 
case against Coleman was found to be insufficient because, as a matter of fact, Coleman neither participated in nor knew of any of the deception practiced upon the plaintiffs and because, as a matter of law, he was under no duty in those circumstances to investigate more than he did or to advise the plaintiffs in any way. ${ }^{105}$ In arriving at its conclusion of law, moreover, the court placed great reliance not only on its findings as to Coleman's non-complicity in the deception but also on his status as an outsider ${ }^{106}$ As an outsider, the court reasoned, Coleman was neither required nor even permitted to intrude on the negotiations with the plaintiffs. ${ }^{107}$ Nor was he liable as a controlling person, since, like Pugliese, he acted in good faith and did nothing to induce the acts of the draftsmen or of the negotiators. ${ }^{108}$

Thus, in the absence of a showing of actual participation in the drafting or use of a misleading prospectus or of actual knowledge of its falsity, an outside director is apparently not liable under rule $10 \mathrm{~b}-5$ for failing to make a reasonable investigation of the sort required by section 11. The primary difficulty with the court's opinion in Lanza, however, surfaces in its attempt to explain this result.

Coleman was said to have satisfied "whatever duty of due diligence there is under Rule $10 \mathrm{~b}-5$ "109 by his personal inquiries to responsible parties within the corporation, even though these same inquiries were not satisfactory for purposes of section 11 of the 1933 Act. ${ }^{110}$ The court distinguished the two provisions by saying that the high standard of diligence of section 11 "is not incorporated in Rule $10 \mathrm{~b}-5$, which applies to all corporate documents and releases, not just to registration statements or prospectuses." 111 Yet, contrary to the suggestion that some investigation is required under rule $10 \mathrm{~b}-5$, the Lanza court absolved Pugliese of liability even though his section 11 liability in BarChris had been predicated on a complete failure to make any inquiries regarding the prospectus. ${ }^{112}$ Further, contrary to the suggestion that the standard of diligence under rule $10 \mathrm{~b}-5$ is not so high as under section 11 , the Lanza court would apparently have been

105. CCH FED. SEC. L. REP. If 92,826, at 90,104. See note 104 supra and accompanying text.

106. CCH FEd. SEC. L. REP. If 92,826, at 90,104, 90,105 n.18.

107. Id. at $90,104-05$.

108. Id. at 90,105-06.

109. Id. at 90,105 .

110. For the extent of Coleman's inquiries, see note 67 supra.

111. CCH FED. SEC. L. REp. If 92,826, at 90,105.

112. See note 101 supra. 
willing to hold Vitolo to a duty of diligence under rule 10b-5 which was scarcely less strict than his duty of diligence under section 11 had it not been able to infer that he knew the prospectus was misleading. ${ }^{113}$ A more satisfactory explanation of Coleman's non-liability would be that because he did not know of, and was not in fact involved in any way with, the deception of the plaintiffs and because, as an outside director, he had no responsibility for the negotiations with the plaintiffs, Coleman simply did not owe a rule $10 b-5$ duty of diligence to the plaintiffs. ${ }^{114}$ This would be true even though, as a director and as one who signed the misleading prospectus, Coleman owed such a duty of diligence under section 11 to purchasers of the security described in the prospectus. In short, it is not the standard of diligence but the particular conduct proscribed that distinguishes rule 10b-5 liability for a misleading prospectus from that imposed by section 11 of the 1933 Act. Section 11 proscribes the mere act of signing a misleading prospectus, liability for which can only be avoided by making a reasonable investigation of the accuracy of the prospectus prior to signing. Rule $10 \mathrm{~b}-5$, on the other hand, imposes liability for the act of making a misleading statement in connection with the purchase or sale of a security. ${ }^{115}$ Whether the act of signing a misleading prospectus also constitutes "making a misleading statement in connection with the purchase or sale of a security" depends on the signer's knowing or negligent participation in, or supervisory responsibility over, the preparation or employment of the misleading prospectus. If one of these elements is present, the signer may well have as strict a duty of diligence under rule $10 b-5$ as he has under section 11 .

\footnotetext{
113. See text accompanying note 88 supra.

114. This is the only conclusion which could be drawn with respect to Pugliese. See note 101 supra.

115. Significantly, section 12(2) imposes liability for conduct described in much the same way, see note 6 supra, though subject, of course, to a privity requirement which is not present in either a section 11 or a rule $10 \mathrm{~b}-5$ action. See notes $27 \& 38$ supra.
} 